\title{
The Coastal Community Development Project (CCDP) Environmentally Sustainable Empowerment Model in District Merauke
}

\author{
Alexander Phuk Tjilen ${ }^{1 *}$, Samel W. Ririhena ${ }^{2}$, Nur jalal ${ }^{3}$, Leo Antonio ${ }^{4}$, Yohanis E. Teturan ${ }^{5}$, and Welhelmina \\ Jeujanan $^{6}$ \\ ${ }^{1}$ Department of Science of Public Administration, Faculty of Social Science and Political Science, Musamus University, \\ Merauke - Papua - Indonesia \\ ${ }^{2}$ Department of Management, Faculty Of Economy and Business, Musamus University, Merauke - Papua - Indonesia
}

\begin{abstract}
The purpose of this study is to explain 1. How is the process of empowering coastal communities in utilizing the funds of the Government of Indonesia and the International Fund for Agriculture Development (IFAD) in District Merauke; 2. To get a model that can explain factor factors that influence the implementation of coastal community empowerment that is environmentally sustainable and sustainable. The method used in this research is a qualitative research. Research is undertaken by direct observation, literature observation, data collection, interviews, and FDG with parties or agencies that have been involved with the Coastal Community Development Project (CCDP), such as the Marine and Fisheries Service of District Merauke, and the District Merauke fishery community. The result of this research: 1) The model of economic empowerment of coastal communities has encouraged people to use environmentally friendly and sustainable fishing gear. 2) The main factors affecting the successful implementation of coastal community empowerment include: (a) Resource, (b) ability, community, (d) commitment, (e) market (market) f) innovation (innovation) and (g) Participation (participatory).
\end{abstract}

Keywords: Coastal Community Development Project (CCDP)

\section{Introduction}

The development of potential coastal areas and efforts to exploit coastal areas through fisheries and marine activities are believed to have a major impact on the increase of people's incomes and the economic improvement of a region. The potential development of coastal areas is believed to have multiplier effects, which in turn will provide a spread effect for the growth of various related economic activities, both for coastal areas and surrounding areas. Increased incomes of coastal communities can directly increase the contribution of labour absorption from a minus area and underdeveloped into an area that has economic value by developing the potential of the region. Increased incomes of society indirectly provide economic impact in the form of contribution to the development of the community economy that can increase local revenue in the form of taxes, levies and other receipts.

The positive impact of coastal community empowerment[1] explains that coastal communities can play a larger role in coastal resources management than has been previously acknowledged in Indonesia. If communities are well trained and empowered, they are in line with the results of these studies[2]. Coastal communities have traits or certain characteristics typical / unique. This property is closely associated with the nature of business in the fishery itself. Due to the nature of the fishing effort is strongly influenced by factors such as environment, season and market. In addition to the positive impacts of exploitation of coastal resources also have a negative impact ${ }^{2}$ that the more opportunities and improvements over utilization of the coastal environment, which will harm.

The government's empowerment project for coastal communities known through the Coastal Community Development Project (CCDP) is a collaborative project between the Government of Indonesia and the International Fund for Agriculture Development (IFAD), beginning in 2013. The project is duration of 5 (five) years, from 1 January 2013 to 31 December 2017. Project was being 
implemented at 13 Eastern Indonesian districts: Merauke; Yapen; Southeast Maluku; Ambon; Ternate; Bitung; North Gorontalo; Parepare; Makassar; Kupang; West Lombok; Kubu Raya and Bandung[3].

District Merauke is one of the locations of coastal community development. The target group is coastal community in a village in the coastal area of District Merauke which has poverty level of more than $20 \%$ per village, but has the potential of large sea resources quantities that have not been optimally utilized, both the potential for capture, cultivation and processing products, as well as the lack of market information and the low quantity of processing production of such market-standard quality have had an impact on the slowness opportunities and efforts to improve the welfare of fishing communities. Department of Marine Affairs and Fisheries of Merauke, which are subordinated from the Ministry of Marine Affairs and Fisheries at the district level in formulating its vision, always refer to the vision of the Ministry of Marine Affairs and Fisheries. The vision of the Department of Marine and Fisheries of District Merauke is "Management of Marine Resources and Fisheries Optimally and Responsible, Ensuring the Increase of Production of Marine and Fisheries". To realize the vision, there are several efforts that must be implemented as reflected in the mission of the Department of Marine Affairs and Fisheries of Merauke, namely to improve the management system of marine and fishery resources; improve the development and development of the resources of the apparatus, fishermen and fish farmers; providing facilities and infrastructure development of marine and fisheries.

\section{Urgency}

The empowerment of coastal communities for District Merauke needs to be studied more deeply considering the use of foreign aid funds, International Fund for Agriculture Development (IFAD), and government funds.

The purpose of this study will explain:

- How the process of empowerment of coastal communities in utilizing IFAD funds and Government funds in District District Merauke;

- To get a model that can explain factor factors that influence the implementation of coastal community empowerment that is environmentally sustainable and sustainable

\section{Finding And Discussion}

\subsection{Coastal Fisheries Potential}

In general, Fishery Management Area Papua is divided into two, namely; the waters northern Papua incorporated in 717 areas covering the waters of the Cendrawasih Sea and the Pacific with a coastline of 509 nautical miles $(916 \mathrm{~km})$ with an estimated area of 6,110 nautical miles $(11,000 \mathrm{~km} 2)$ as a region rich in Pelagic Great fisheries resources (Tuna, Paruh Panjang, Cakalang and Tenggiri). While in the southern part of Papua, the 718 areas cover the waters of the Arafura Sea with a long coastline of 662 nautical miles $(1.191 \mathrm{~km})$ with an area of 7.944 nautical miles $(14,300 \mathrm{~km})$ and is rich in
Demersal Fish resources (shrimp, Kakap Merah, Kakap White, Bawal, Pari, Cucut and also other small Pelagic Fish (Teri, Tongkol, Kembung). The other group of fish are Grouper Fish, Napoleon, Lobster and ornamental fish. Palang has great potential of natural resources, especially in coastal area and sea. This resource can be seen from the various tropical ecosystems (mangroves, coral reefs and sea grass beds) with a high level of diversity. In addition, Papua also has the potential of biological fishery resources, especially the northern waters of Papua with Pelagic potential and the southern waters with the main commodity shrimp, minerals, minerals and gas resources can also be found in coastal ran and the Papua Sea. Fishery activities can be said to be relatively simple. The types of fishing gear used by local people are still traditional, for example gill nets, fishing rods and other fishing gear such as tents, spears and kalawai (many-edged spears). Sampan used by fisherman as a means of transportation to the fishing ground (fishing ground) with travel time for 0.5 - 2 hours. In general, fishermen use boats without motorboats in the form of rowing boats / boat / landlady and motorboat. Capacity of motor engine used $15 \mathrm{pk}, 25 \mathrm{pk}$, and $40 \mathrm{pk}$. Generally the 40 pk propulsion machine owned by each village is a government aid. But because of high fuel prices then the motor is rarely used.

\subsection{Problems Surrounding the Empowerment and Focus of the IFAD Program}

Many government projects/programs have been undertaken to encourage economic development of rural communities. Projects/programs are carried out by each department or between departments. Empowerment problems faced such as: (1) economically, unsuccessfulness in providing an income upgrade towards the society; (2) psychologically, the lack of confidence and knowledge of tourism among the people; (3) socially, the existence of apathy by the people due to the lack of trust; (4) politically, the unrealized programs by the people due to the lack of decision making and participation[4].

Programs/methods offered by CCDP are 1) community empowerment, development and resource management on village participatory approach working through community groups; 2) district support for marine-based economic development on investments at the district level to support villages; 3) project management on national, district and village level, with the offered program is expected to achieve empowerment program and can increase the income of coastal communities.

Compared to previous generations, the results of longer projects exploited by the community and even growing positively impact the problems that are often encountered in the environmental potential of La Sara[5] explains, in general, those degradation of coastal and marine ecosystems led to low income of coastal communities which turn have been affecting welfare, health, sanitation, education, lack of job, and other social problems.

One of the solutions is integrated coastal management, which is an accepted management framework to address coastal and marine environmental problems and conflicts and to achieve, sustainable use of coastal resource. The results of the discussion explain the use of fishing gear used 
by the coastal communities of District Merauke also generally still use a simple tool net, this is in line to the Ministry of Marine Affairs and Fisheries regulation Number 2 of 2015 about prohibiting the use of the fishing gear trawl and seine nets in the Area of Fishery Management of the Republic of Indonesia, so both of these fishing gear is no longer used[6] thus the use of these simple fishing gear supports the implementation of the ecosystem and the sustainability of the IFAD-funded community effort

\subsection{Program Implementation and Inhibition of Program Implementation}

The success of the program cannot be separated by several factors that support both the external environment and the internal program itself. Implementation of this program is supported by several factors including:

- Availability of resources or potential of human resources and natural resources potential to be developed. How committed to the implementation of the target. This is reflected in the close collaboration of all elements of both the department that admires the program, the apparatus that runs these activities and the resources available.

- The involvement of other stakeholders who support the implementation. Involvement can be in the form of socialization, training and seminar from Department of Fishery and Marine to improve the performance of the implementer.

- Active community participation not only receiving information but also providing opinions on ideas and thoughts in order to improve the welfare and resilience of the community pursued by physical and non-physical development.

Facing various problems and obstacles in the implementation of the Coastal Community Development Project (CCDP) program in District Merauke occurred in its implementation. Several factors affecting the project's problems include:

- Inappropriateness between community needs and assistance provided

- Project package not equipped with supportive skills

- No planned monitoring activities

- No institution the community level who continue the project.

Discussion results explain that the boat provided by the program does not match the technical factors and natural conditions, so the boat is easy to turn, while the coast of District Merauke facing the open sea which resulted in huge waves. Learning from these failures, the next generation of projects began to be complemented by other aspects such as training for skills, institutional formation at the community level, the presence of field officers, involving nongovernmental organizations (NGOs). Or in other words some projects are managed with a community empowerment approach that is appropriate to the condition and culture society.

\subsection{Model Factor Affecting the Implementation of Coastal Communities Empowerment}

The main factors affecting successful implementation of empowerment include[7]:

\subsubsection{Capital}

Capital becomes the main requirement to be developed a program, thus required ability, understanding of society, commitment and market that will accommodate the production. It should be understood that all these factors cannot stand alone, but must be integrated with other factors.

\subsubsection{Resources}

Resources referred here are assets in the form of potentials that can be used as capital resources, either in the form of money or goods that can be used as working capital, including how access to financial institutions.

\subsubsection{Ability}

In the framework of management and business development required skills, knowledge and experiences that can be used as a basis in work. For this reason it is only natural that the assistance provided should be based on the members' skills, experience and knowledge.

\subsubsection{Environment}

The concept of the environment is how to understand the things that connected with the living conditions of the environment with the values, norms and culture of society and vice versa how the support of community values and norms, how the relationship with formal and informal leaders of society and vice versa how the relationship formal and informal community has a socialization mechanism to form the personality of its members according to the symbols it possesses.

Associated with this concept, then the existence in society must be integrated as a whole with the concept of community. In addition, life will be an inseparable part of the local population, possibly to be used as a venture capital, may be a companion, thereby fully accepted by society and even supported by the community. A community always has a culture or habits and values and norms agreed upon that govern the behaviour of its members. This habit can be a written and unwritten rule. Morally all citizens are encouraged to follow it, if any citizen who does not obey it will usually be ostracized.

\subsubsection{Commitment}

Commitment is an important element in life especially in business. It is hoped that people who become members really have a high commitment to join, and must try as hard to promote and develop so that it can succeed. There is a strong duty to carry out the task with full responsibility. Commitments included in this study include: the motivation members have to join, the perception of group life, the fulfilment of members' needs and expectations, and the main source of income. 


\subsubsection{Market}

The market in question here is an opportunity owned in marketing the results of operations, how the availability of resources that can be utilized. Empowerment has been less market-minded. From existing data that access to markets is largely new at the environmental and local levels, only a few have reached regional and global levels. Of course this condition is very apprehensive. This can happen because it does not consider the market conditions, the market affordability and so on. The market has its own concept.

The market needs to consider several things: (a) target / consumer, (b) quality, how the quality should be made. Quality indicator is customer satisfaction. (c) production and profit, how much goods to produce, so as not to exceed market demand. (d) competitors, how rivals exist, whether able to compete or beat competitors or vice versa. All these aspects should be considered carefully before choosing the type of productive business developed. The ability to consider all of these will be one of the success factors, one that can be used to use an existing network of fellow IFAD members, while also utilizing a trained companion.

\subsubsection{Innovation}

Technolgy in question is the innovations undertaken by in order to boost working productivity. Departing from this concept, innovation does not always have to be construed as complicated and high-tech, but something new by both a person and an organizational group. The "new" in the concept of innovation is something different from the methods already practiced, but is directed to more practical, productive, simple or simple, effective and efficient and more productive.

Innovation implementation is still very limited, only seen on some techniques of fishing and fish management is still very simple. Of course this can not be separated from the education level of members who generally are high school and below. Due to the lack of application of innovation so that development is also limited. In business development, members only rely on manual processes that are already very familiar with life so far. They are very difficult to abandon their habits

\subsubsection{Participation}

Participation in the meaning of empowerment implies the involvement of the community in every activity in a program, so that will be achieved process community economic empowerment local as "it should start with institutional empowerment with reach form delegation empowerment organization, empowerment and individual empowerment"[8]. Community empowerment cannot be separated from the participation of stakeholders and the community and companies in the form of CSR in the empowerment of the community need to pay attention to opportunities, threats, problems and potential local resources that exist. The requirement for participation from stake holders[9]. Although these studies suggest that stakeholder participation may improve the quality of environmental decisions, but the quality of a decision is strongly dependant on the quality of the process that leads to it.

\section{Conclusions}

The proposed model of economic empowerment of coastal communities cannot be implemented partially. The planned program has encouraged the community to use environmentally friendly and sustainable fishing gear, but there are still some weaknesses in its implementation. Additional attention to considerable innovation will therefore increase the welfare of the community, in the form of fishing gear facilities, postcatchment fish processing techniques, increased selling prices in the form of larger money markets, by utilizing the participative potential of companies already serving the national market and export markets. Potentials in the form of human capability are also gained attention given the training and comparative study opportunities as well as the addition of counsellors from the developed regions, this can be pursued by the exchange of counterparts from the existing IFAD programs in more developed areas, thus the training and mentoring process will get a new knowledge both for the community as well as program counterparts

Opportunities that can be developed include: (1) cooperation in the utilization of corporate contributions in the development of community through the allocation of planned CSR funds in the medium term and long term, (2) utilize the available state funds by optimizing the role of fisheries extension, 3 ) exploiting the existence of institutions of higher education and institutional non-governmental organizations through the development of synergic partnership between the role of Local Government, Private, Community and Higher Education.

\section{References}

1. J.J. Tulungen, P. Kussoy, B.R. Crawford, Community Based Coastal Resources Management in Indonesia: North Sulawesi Early Stage Experiences, (1998)

2. Y. Wahyudin, General Socio-Economic Profile Of Coastal Community, (2013)

3. G.S. Putra, C. Greenwald, Coastal Community Development Project Experience And Lessons Learned, (2017)

4. H. Angger, M. Rahmanita, H. Hermantoro, Community Empowerment in Plempoh Cultural Tourism Village, (2017)

5. L. Sara, A. Hamid, Safilu, Empowering Coastal Community By Implementing Natural Resources Management (Case study in Southeast Sulawesi, Indonesia), (2011)

6. BPS, Statistics Of Marine And Coastal Resources 2016, (2016)

7. J. Tampubolong, Pemberdayaan Masyarakat Melalui Pendekatan Kelompok Kasus Pemberdayaan Masyarakat Miskin melalui Pendekatan Kelompok Usaha Bersama (KUBE), (2006)

8. A.P. Tjilen, F. Papilaya, E. Cahyono, Implementation of the Economic Program Empowerment of Local Communities in Sota District, District Merauke Sub District, (2016)

9. M.S. Reed, Review Stakeholder Participation for Environmental Management, (2008) 